\title{
$\mathrm{Fe}-22 \% \mathrm{Cr}-5.8 \% \mathrm{Al}$ 합금의 고온 산화 거동
}

\author{
김송이 ${ }^{a}$, 최성환 $^{a}$, 윤중열 $^{b}$, 공영민 $^{c}$, 김병기 $^{c}$, 이기안 $^{a^{*}}$ \\ a안동대학교 신소재공학부, ${ }^{b}$ 한국기계연구원 부설 재료연구소 기능재료연구본부 \\ "울산대학교 첨단소재공학부
}

\section{High-Temperature Oxidation Behavior of Fe-22\%Cr-5.8\%Al Alloy}

\author{
Song-Yi Kima, Sung-Hwan Choi ${ }^{\mathrm{a}}$, Jung-Yeul Yun ${ }^{\mathrm{b}}$, Young-Min Kong ${ }^{\mathrm{c}}$, \\ Byoung-Kee Kim ${ }^{\mathrm{c}}$, Kee-Ahn Lee ${ }^{\mathrm{a*}}$ \\ ${ }^{a}$ School of Advanced Materials Engineering, Andong National University, Andong 760-749, Korea \\ ${ }^{\mathrm{b}}$ Department of Materials Engineering, KIMM, Changwon 641-010, Korea \\ 'School of Materials Science Engineering, University of Ulsan, Ulsan 680-749, Korea
}

(Received January 27, 2011 ; revised February 18, 2011 ; accepted February 27, 2011)

\begin{abstract}
This study investigated the high temperature oxidation behavior of $\mathrm{Fe}-22 \% \mathrm{Cr}-5.8 \% \mathrm{Al}$ alloy and the oxidation kinetics of the alloy were discussed. Bulk samples were prepared by VAM (vacuum arc melting) and hot forging. High temperature oxidation testes were isothermally conducted up to 100 hours in $79 \% \mathrm{~N}_{2}+21 \% \mathrm{O}_{2}$ environment at three different temperatures $\left(900^{\circ} \mathrm{C}, 1000^{\circ} \mathrm{C}, 1100^{\circ} \mathrm{C}\right)$. The weight gain was measured after oxidation according to oxidation time $(2,4,6,8,10,15,20,25,30,60,80,100$ hours). The weight gain significantly increased with increasing oxidation temperature. As the temperature increased, the oxidized samples showed sequential formation of $\mathrm{Al}_{2} \mathrm{O}_{3}, \mathrm{Cr}$-rich oxide, Fe-rich oxide. The activation energy of high temperature oxidation was obtained as $306.63 \mathrm{KJ} / \mathrm{mol} . \mathrm{Al}_{2} \mathrm{O}_{3}$ were developed on the surface in the early stage of oxidation, representing protective role of oxidation. However, Fe-based and Cr-based oxides leaded to breakaway of oxide layer, thus resulted in the significant increase of additional oxidation.
\end{abstract}

Keywords : Fe-22\%Cr-5.8\%Al, High temperature oxidation, Oxidation time, Oxidation kinetics, Oxides

\section{1. 서 론}

$\mathrm{Fe}-\mathrm{Cr}-\mathrm{Al}$ 합금은 고온에서 재료의 표면에 보호성 $\mathrm{Al}_{2} \mathrm{O}_{3}$ 를 형성시킨다. $\mathrm{Al}_{2} \mathrm{O}_{3}$ 는 산화 시 초기에 빠르 게 형성되어 고온에서 성장 속도가 느리고 화학적 안정성이 우수한 장점을 갖는다 ${ }^{1)}$. 그 결과 $\mathrm{Fe}-\mathrm{Cr}-$ $\mathrm{Al}$ 합금은 산화층의 급속한 성장이 억제되고 고온 에서 우수한 내열, 내산화성을 가지는 것으로 알려 져 있다 ${ }^{2-4)} . \mathrm{Fe}-22 \% \mathrm{Cr}-5.8 \mathrm{Al}$ 합금은 $1400^{\circ} \mathrm{C}$ 까지 사 용 가능한 재료로써 전열선, 발열체 등 고온 분야 에 적용되고 있다. 최근에는 이런 특성을 바탕으로

*Corresponding author. E-mail : keeahn@andong.ac.kr
자동차 배기가스 정화 장치, 금속 담체(metal honey $\mathrm{comb}$ ) 등 주로 고온에서 장기간 적용되는 분야에 응용하려는 연구가 진행되고 있다 ${ }^{5}$. 이에 장시간 시 간에 따른 고온 산화 거동 및 내산화 수명 향상에 대한 관심이 대두되고 있다.

한편 현재까지 $\mathrm{Fe}-\mathrm{Cr}-\mathrm{Al}$ 계 합금에 대해서 $\mathrm{Fe}-$ $\left.35 \% \mathrm{Cr}-5 \% \mathrm{Al}^{6}\right), \mathrm{Fe}-20 \% \mathrm{Cr}-5 \% \mathrm{Al}^{7)}$ 등 여러 조성의 고온 산화 거동에 대한 연구가 보고되었다. 또한 합 금 내 $\mathrm{Al}^{8)}$ 및 $\mathrm{Cr}^{9}$ 함량 변화에 따른 내산화 향상 거동에 대한 연구도 진행된 바 있다. 합금 원소 첨 가에 따라서는 $\mathrm{Y}^{(0-12)}, \mathrm{Zr}^{13)}, \mathrm{La}^{14,15)}, \mathrm{Hf}^{(1)}$ 등 희토류 원소의 첨가로 금속 기지와 산화층간의 접착력 향 상을 시도한 연구들이 활발히 진행되었다. 그러나 
$\mathrm{Fe}-22 \% \mathrm{Cr}-5.8 \% \mathrm{Al}$ 에 대한 연구 결과는 부분적으로 분말 소결재를 이용한 고온 산화 거동에 대한 연구 가 제시되어 있고 벌크재에 대한 고온 내산화 특성 에 대한 연구는 부족한 실정이다. 특히 시간에 따 른 고온 산화 거동에 대한 연구는 산화 초기에 일 어나는 산화 거동 대한 연구 결과가 ${ }^{17)}$ 대부분이고, 장기간의 고온 산화 시 시간의 증가에 따른 고온 산화 거동 및 산화 생성상을 통한 미세기구를 규명 한 연구가 미흡한 실정이다.

본 연구에서는 $\mathrm{Fe}-22 \% \mathrm{Cr}-5.8 \% \mathrm{Al}$ 의 벌크재의 100 시간 동안 세 가지 온도 $\left(900^{\circ} \mathrm{C}, 1000^{\circ} \mathrm{C}, 1100^{\circ} \mathrm{C}\right)$ 에 서 고온 산화 실험을 수행하여 시간에 따른 고온 산화 거동을 조사하고 이에 대한 미세조직 및 산화 생성상을 비교, 분석하여 $\mathrm{Fe}-22 \% \mathrm{Cr}-5.8 \% \mathrm{Al}$ 소재의 고온 산화 미세 기구를 규명하고자 하였다.

\section{2. 실험 방법}

본 연구에서는 $\mathrm{Fe}-\mathrm{Cr}-\mathrm{Al}$ 계 합금 중 고온 특성이 우수하다고 알려진 $\mathrm{Fe}-22 \% \mathrm{Cr}-5.8 \% \mathrm{Al}(\mathrm{wt} . \%)$ 합금을 사용하였다. 먼저 기본 소재로 상기 조성, 직경 $\Phi 0.3 \mathrm{~mm}$ 전열선을 사용하였다. 고온 산화 시편 제 조를 위해 전열선을 작게 절단하여 고 진공 아크 용해로(high vacuum arc melting furnace)에서 용해 시켰다. 시편 내 조성을 균일화하기 위해 $4 \times 10^{-5}$ Torr의 진공 조건에서 5회 교반, 용해시켜 버튼 형 태의 시편을 제조하였다. 용해 제조 시 생성된 수 축공과 내부 기공의 제거를 위해 $1100^{\circ} \mathrm{C}$ 에서 30 분간 예열한 후에 50 톤의 하중으로 열간 단조하여 초기 시편을 제조하였다. 이후 초기 시편을 $7 \times 7 \times 1 \mathrm{~mm}^{3}$ 의 크기에 형상으로 가공하고 고온 등온산화 실험 수행 시 전열선을 걸어 고정시킬 구멍을 직경 $1.5 \mathrm{~mm}$ 의 크기로 뜷어 제작하였다. 제작된 시편의

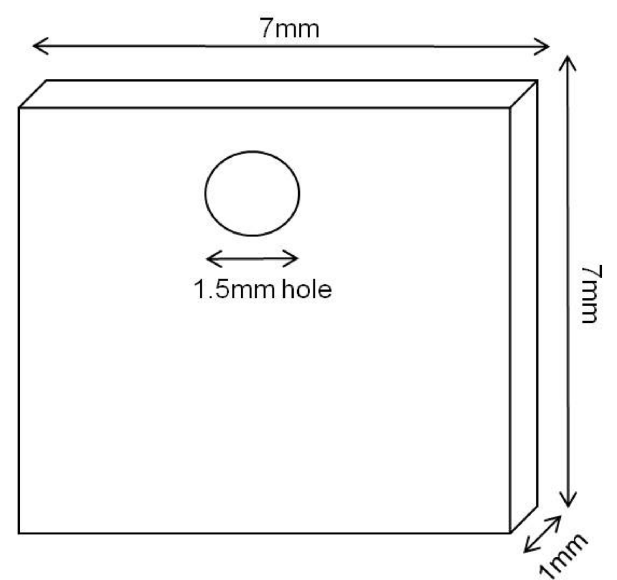

Fig. 1.Specimen morphology for high-temperature oxidation test.
총 표면적은 $127.18 \mathrm{~mm}^{2}$ 이었다. 산화 시 표면 거 칠기의 영향을 일정하게 하기 위해 $\mathrm{SiC}$ Paper로 \#2000까지 연마하였다. 상기의 방법으로 제조된 고 온 산화용 최종 가공 시편 형상을 그림 1 에 나타 내었다.

고온 등온 산화 실험은 $900^{\circ} \mathrm{C}, 1000^{\circ} \mathrm{C}, 1100^{\circ} \mathrm{C}$ 세 가지 온도 조건에서 수행하였다. 산화는 대기와 유 사한 gas 분위기 $\left(79 \% \mathrm{~N}_{2}+21 \% \mathrm{O}_{2}\right)$ 하에서 수행되었 으며 실험을 위하여 box electric furnace(TAG061015)를 사용하였다. 시간에 따른 고온 산화의 거 동을 관찰 하기 위해 온도에 따라 각각 $2,4,6,8$, $10,15,20,25,30,60,80,100$ 시간 동안 수행하였 다. 세 가지 온도의 고온 산화 실험에서 모두 $5^{\circ} \mathrm{C} /$ $\min$ 의 속도로 승온시켰다. 가스의 유입량은 각각 반응 온도에서 유속이 $1 \mathrm{l} / \mathrm{min}$ 이 되도록 조절하였 다. 시편의 산화 실험 전의 미세조직 관찰과 산화 시간에 따라 생성된 산화층의 미세조직 분석을 위 해서 주사전자 현미경(SEM)과 전계 방출형 주사 전자 현미경(FE-SEM) 및 광학 현미경 $(\mathrm{OM})$ 을 사용 하였다. 또한 산화 전 - 후 생성된 상의 관찰은 Xray와 EDS를 통해 분석하였다.

\section{3. 실험 결과}

상기의 방법으로 제조된 $\mathrm{Fe}-\mathrm{Cr}-\mathrm{Al}$ 합금의 시간 및 온도에 따른 고온 산화 실험을 수행하여 그 결과를 그림 2에 도시하였다. 시간이 증가함에 따라 세 가 지 온도 모두 산화 증량이 증가하였지만 각각 시간 에 따라 다른 거동을 내었다. $900^{\circ} \mathrm{C}$ 의 경우 시간의 증가에 따라 산화 증량이 크게 증가하지 않았으며 아주 조금씩 산화 증량의 증가가 일어났다. $1000^{\circ} \mathrm{C}$ 에서는 크게 세 구간으로 나뉘어 지는데 초기부터 30 시간까지는 산화 증량의 증가가 조금씩 일어났다.

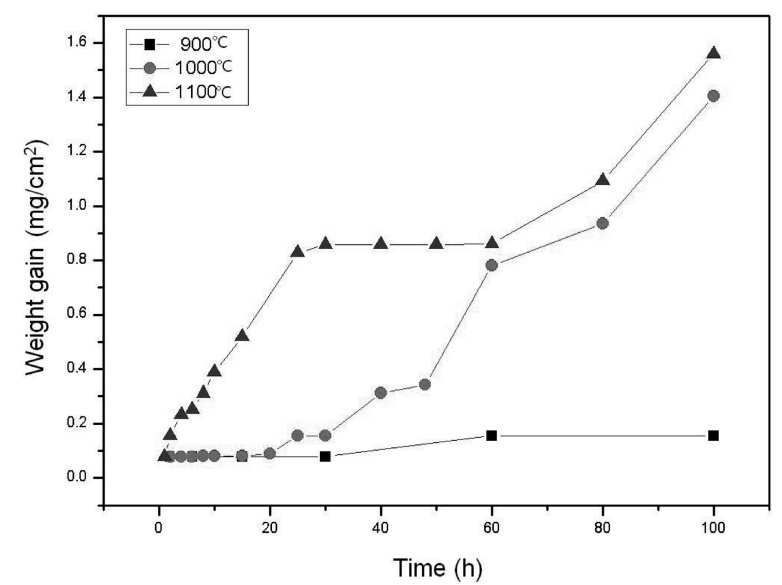

Fig. 2. Effect of temperature and time on the oxidation weight gain of $\mathrm{Fe}-22 \mathrm{Cr}-5.8 \mathrm{Al}$ in $79 \% \mathrm{~N}_{2}+21 \% \mathrm{O}_{2}$. 
30 시간에서 50 시간까지는 점차적으로 기울기가 증가 하였으며, 50 시간 이후에는 급격한 기울기로 산화 증량이 증가하는 것을 알 수 있다. $1100^{\circ} \mathrm{C}$ 에서는 이전 온도와는 확연한 차이를 보였는데, 초기부터 25시간까지 급격한 기울기로 직선적 무게 증가 거 동을 나타냈다. 그 이후 60 시간까지 산화 증량의 증가가 거의 일어나지 않는 거동을 보였다. 그러나 60 시간 이후 또 다시 급격한 기울기로 산화 증량의 증가 거동을 보였다. $1100^{\circ} \mathrm{C}$ 에서는 $900^{\circ} \mathrm{C}$ 와 $1000^{\circ} \mathrm{C}$
에 비해 모든 시간에서 가장 큰 산화 증량 값을 나 타냈다. 100 시간에는 $900^{\circ} \mathrm{C}$ 에서 $1100^{\circ} \mathrm{C}$ 로 산화 온 도가 증가함에 따라 산화 증량이 $0.156 \mathrm{mg} / \mathrm{cm}^{2}$ 에서 $1.56 \mathrm{mg} / \mathrm{cm}^{2}$ 으로 10 배 가량 증가하였으며 이에 현 저히 낮은 내산화성을 보였다.

그림 3에 세 온도 $\left(900^{\circ} \mathrm{C}, 1000^{\circ} \mathrm{C}, 1100^{\circ} \mathrm{C}\right)$ 에서 100 시간 동안 산화 실험한 산화층의 표면을 관찰한 결 과 중 온도 및 시간별로 대표적인 것들을 나타내었 다. 그림에서 온도에 따라 각각 다른 형태의 표면
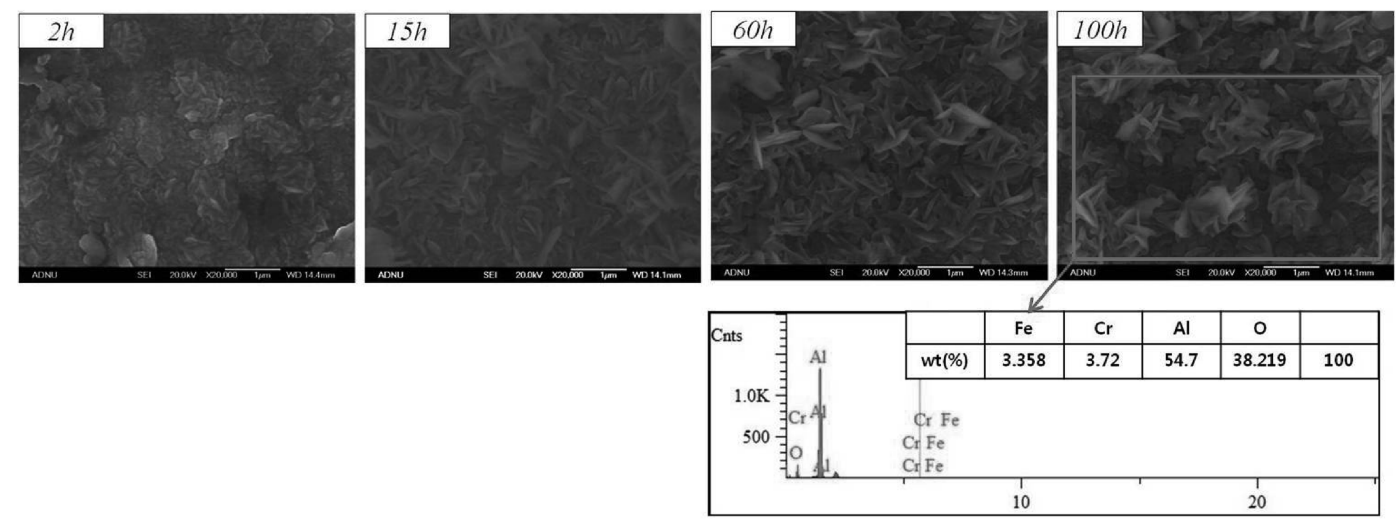

(a)
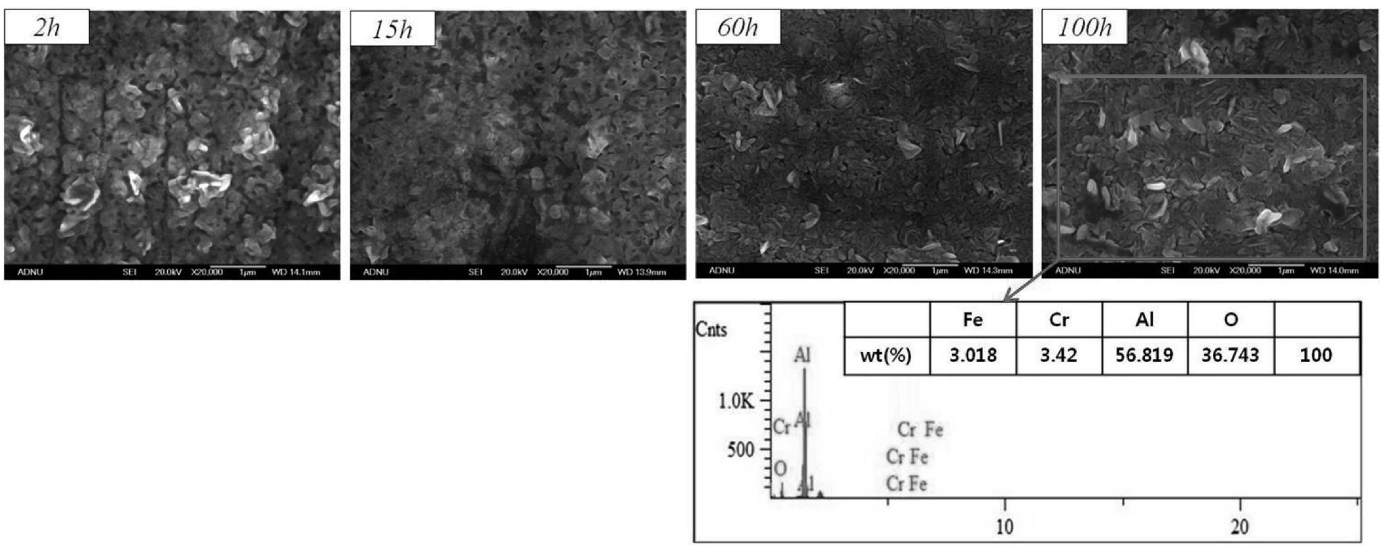

(b)
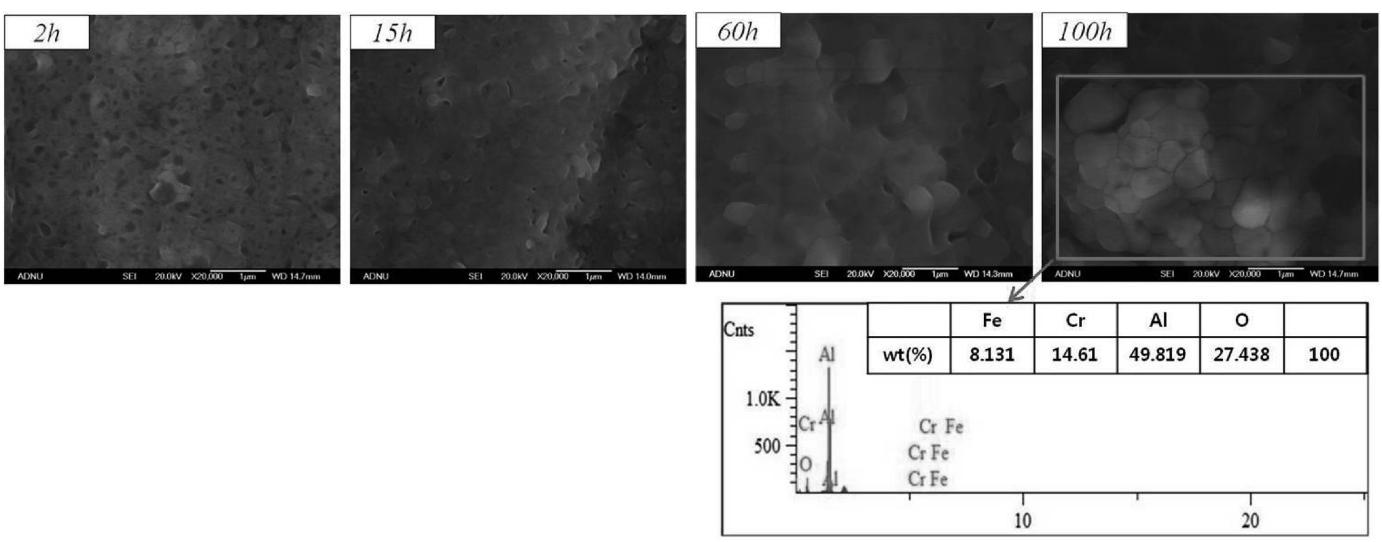

(c)

Fig. 3. Surface morphologies of oxide layer on Fe-Cr-Al alloy with oxidation time (a) $900^{\circ} \mathrm{C}$, (b) $1000^{\circ} \mathrm{C}$, (c) $1100^{\circ} \mathrm{C}$. 
산화물이 관찰되는 것에 주목할 만하다. 그림 (a)는 $900^{\circ} \mathrm{C}$ 에서 산화된 시편의 표면으로, 시간이 지남에 따라 초기 2시간에서 60 시간까지는 산화물의 성장 이 이루어 졌지만 60 시간 이후 100시간까지 표면 산화물의 성장이 거의 일어나지 않는 것을 관찰할 수 있다. 형성된 산화물은 whisker 형태로 관찰되 었으며 $\mathrm{EDS}$ 분석 결과 대부분이 $\mathrm{Al}_{2} \mathrm{O}_{3}$ 로 나타났다. (b)의 $1000^{\circ} \mathrm{C}$ 에서 산화된 시편에서도 초기 2 시간부
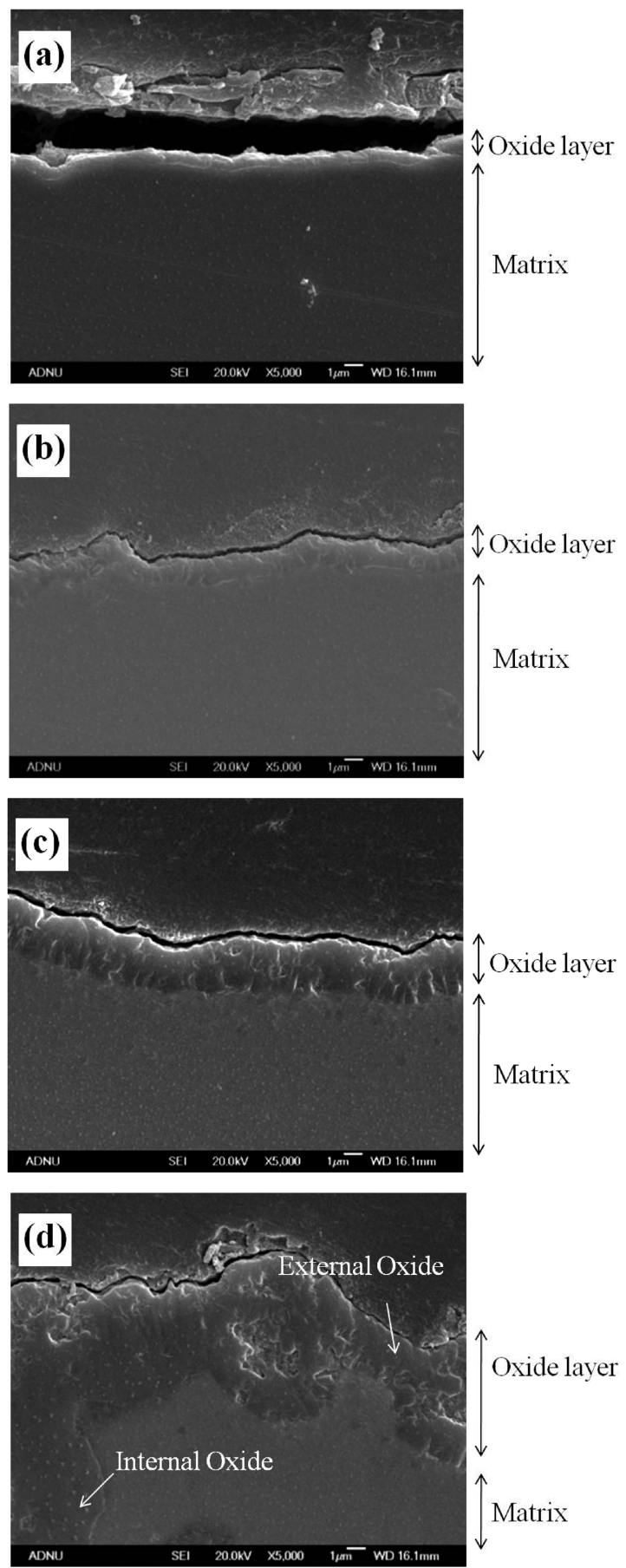

Fig. 4. Growth of oxide layer on Fe-Cr-Al alloy with oxidation time at $1100^{\circ} \mathrm{C}$ (a) $2 \mathrm{~h}$, (b) $15 \mathrm{~h}$, (c) $60 \mathrm{~h},(\mathrm{~d}) 100 \mathrm{~h}$.
터 60시간까지 산화물 입자가 성장하는 경향을 나 타냈다. 그러나 60 시간 이후 100 시간까지는 입자 크기가 거의 유사하게 나타났다. 상기의 결과에서 60시간 이후 산화 증량값(그림 2)의 급격한 증가가 나타났지만 표면의 산화층은 거의 변화가 없었다. 또한 $900^{\circ} \mathrm{C}$ 에서 whisker형으로 형성된 산화물과 달 리 globular한 형태로 산화물이 성장한 것을 알 수 있었다. 산화물의 입자 크기는 $900^{\circ} \mathrm{C}$ 와 유사하게 나타났다. $1000^{\circ} \mathrm{C}$ 의 표면EDS 분석 결과 역시 대부 분이 $\mathrm{Al}_{2} \mathrm{O}_{3}$ 인 것으로 나타났다. 그림 $(\mathrm{c})$ 는 $1100^{\circ} \mathrm{C}$ 에서 산화된 시편의 표면으로 $900^{\circ} \mathrm{C}$ 와 $1000^{\circ} \mathrm{C}$ 에 비 해 초기 2시간부터 산화물 크기가 조대하게 나타남 을 알 수 있었다. 시간의 증가에 따라 60시간 이후 다른 온도 $\left(900^{\circ} \mathrm{C}, 1000^{\circ} \mathrm{C}\right)$ 에 비해 산화물 입자의 크 기가 확연히 커진 것을 관찰할 수 있다. 또한 입자 들이cluster를 이루며 거대한 산화물로 형성되어 산 화층의 성장이 일어난 것도 확인할 수 있었다. 세 가지 온도에서 시간의 증가에 따른 산화물 성장의 차이가 나타났으며 온도에 따라 다른 형태의 산화 물이 나타났다.

산화 실험 후 시편의 산화층 단면을 관찰한 결과, 기본적으로 모든 온도 조건 $\left(900^{\circ} \mathrm{C}, 1000^{\circ} \mathrm{C}, 1100^{\circ} \mathrm{C}\right)$ 에서 시간이 증가함에 따라서 산화층의 두께가 증 가하였다. 그림 4 에 시편의 단면을 보여 주는 예로 써 $1100^{\circ} \mathrm{C}$ 에서 시간의 증가에 따라 $2,15,60,100$ 시간 동안 산화한 시편의 산화층 두께 차이를 나타 내었다. 초기 2시간(a)에서 약 $0.656 \mu \mathrm{m}$ 로 외부에 얇은 산화층이 형성되었다. 이후 15 시간 (b) 이후 산화층의 성장이 일어나 $1.222 \mu \mathrm{m}$ 두께의 산화층을 형성하였다. 시간의 증가에 따라 계속적인 산화층 성장이 일어나 60 시간 (c) 후에는 $2.463 \mu \mathrm{m}$ 로 약 2 배 정도 두께의 산화물을 관찰할 수 있었다. 최종적으 로 100 시간 (d) 후 매우 많은 양의 산화가 일어남 을 확인하였으며 내부로 산소 확산이 활발하게 일 어나 다량의 산화물이 내부에 형성되어 있는 것을 알 수 있다.

세 온도 조건에서 산화 시간에 따른 $\mathrm{XRD}$ 분석 을 수행하였으며 그 중 대표적인 시간들의 실험 결 과들을 그림 5에 나타내었다. 산화 전 XRD 결과에 서는 $\alpha-\mathrm{Fe}$ 단상의 peak만 나타났으며 산화물의 peak 는 검출되지 않았다. $900^{\circ} \mathrm{C}$ 에서는 시간이 증가함에 따라 산화 초기인 2시간 후에 $\alpha-\mathrm{Al}_{2} \mathrm{O}_{3}$ 가 검출되었 다. 또한 25 시간 이후 이전 시간에서 희미하게 나 타나던 $\alpha-\mathrm{Al}_{2} \mathrm{O}_{3}$ peak가 명확히 검출되었다. $1000^{\circ} \mathrm{C}$ 에서도 $900^{\circ} \mathrm{C}$ 에서 관찰되었던 산화물이 검출되었 다. 2 시간 후에 $\alpha-\mathrm{Al}_{2} \mathrm{O}_{3}$ 가 검출되었으며, $900^{\circ} \mathrm{C}$ 보 다 더 빠른 시간인 15 시간 후에 $\alpha-\mathrm{Al}_{2} \mathrm{O}_{3}$ peak가 


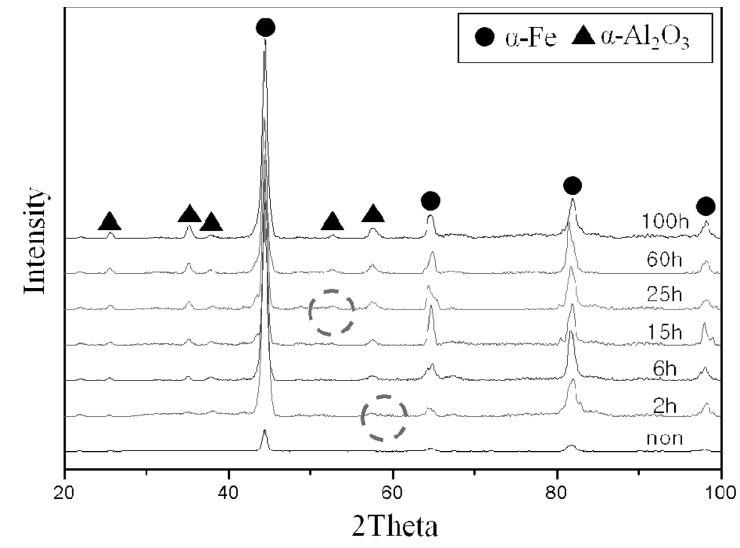

(a)

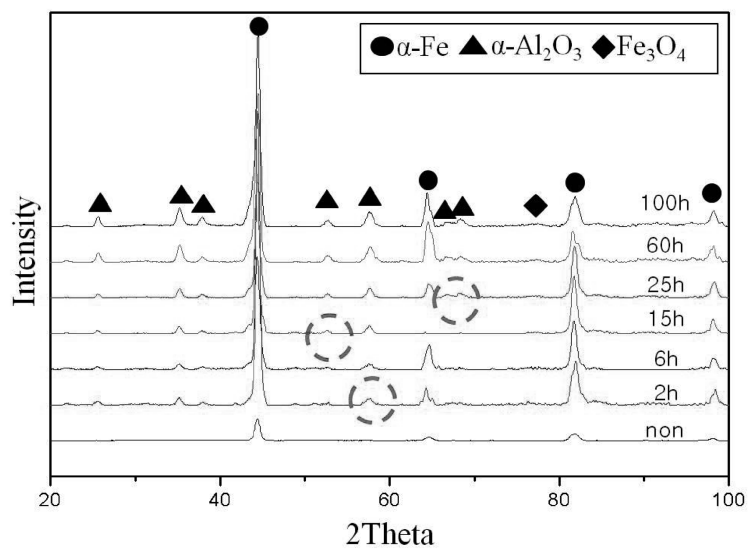

(b)

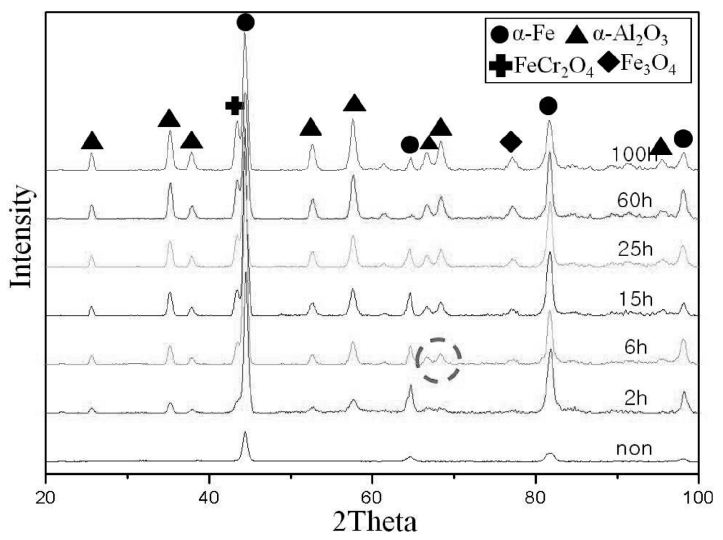

(c)

Fig. 5. XRD analysis results of Fe-22Cr-5.8Al Bulk specimen, oxidized for 100 hours at $900^{\circ} \mathrm{C}$ (a), $1000^{\circ} \mathrm{C}(\mathrm{b}), 1100^{\circ} \mathrm{C}$ (c).

더 검출되었다. 25 시간 이후에는 $900^{\circ} \mathrm{C}$ 에서는 흔적 만 나타나던 $\alpha-\mathrm{Al}_{2} \mathrm{O}_{3}$ peak가 $1000^{\circ} \mathrm{C}$ 에서 명확히 검 출되었다. 또한 $\mathrm{Fe}_{3} \mathrm{O}_{4}$ peak가 희미하게 관찰되었다. 이것은 앞의 산화 증량값에서 25 시간 이후 산화 증 량이 급격히 증가한 결과와 상응하는 결과를 나타 내고 있다. $1100^{\circ} \mathrm{C}$ 고온에서 산화시킨 경우 다량의 산화물이 검출되었으며, 새로운 산화물이 추가로 관
찰되었다. 2시간 이후에는 $900^{\circ} \mathrm{C}, 1000^{\circ} \mathrm{C}$ 에서 관찰 되었던 $\alpha-\mathrm{Al}_{2} \mathrm{O}_{3}$ 가 동일하게 검출되었다. 또한 이전 의 온도에서 존재하지 않았던 $\mathrm{FeCr}_{2} \mathrm{O}_{4}$ 및 $\mathrm{Fe}_{3} \mathrm{O}_{4}$ peak들이 나타났다. 이 peak들은 6시간 후에 명확 하게 관찰되었다. 상기의 결과에서 시간에 따라 생 성되는 산화물의 양이 증가해 나타나는 것을 알 수 있다. 이와 함께 온도가 증가함에 따라 형성된 산 화물이 명확해 지는 것을 알 수 있다. 또한 온도 증 가에 따라 형성되는 산화물의 종류가 다양하고 많 은 양이 검출됨에 따라 많은 산화가 진행됨을 알 수 있었다.

그림 6은 산화층에서 생성된 상 및 분포를 알아 보기 위해 세 온도 조건 $\left(900^{\circ} \mathrm{C}, 1000^{\circ} \mathrm{C}, 1100^{\circ} \mathrm{C}\right)$ 에 서 100 시간 동안 산화시킨 후 $\mathrm{EDS}$ 조사한 결과를 나타내었다. (a)는 $900^{\circ} \mathrm{C}$ 에서 산화한 결과로 외부 산화층이 시편의 표면에 얇게 형성되어 있는 것을 알 수 있다. 또한 내부에도 산화층이 형성된 것을 관찰할 수 있으며, $\mathrm{EDS}$ 측정 결과 주로 $\mathrm{Al}_{2} \mathrm{O}_{3}$ 로 나 타났다. 그러나 (b)에서 $1000^{\circ} \mathrm{C}$ 로 온도가 증가함에 따라 더욱 깊은 부분까지 내부 산화물(internal oxide) 이 분포하고 있고, $\mathrm{Al}_{2} \mathrm{O}_{3}$ 외에 다른 산화물이 추가 적으로 나타났다. 추가로 형성된 산화물은 $\mathrm{Cr}$ 및 $\mathrm{Fe}$ 계 산화물로 $\mathrm{Al}_{2} \mathrm{O}_{3}$ 층 아래 형성되었다. 이 결과 는 XRD에서는 명확히 나타나지 않았지만 $\mathrm{EDS}$ 분 석을 통해 확인할 수 있었다. 또한 기지 내 $\mathrm{Al}$ 과 결합하여 내부 결정립계를 따라 $\mathrm{Al}_{2} \mathrm{O}_{3}$ 가 형성된 것 을 관찰할 수 있었다. 이와 동시에 내부에서 결정 립계를 따라 $\mathrm{Cr},(\mathrm{Fe}, \mathrm{Cr})$-산화물 들이 새롭게 생 성, 성장한 것을 확인할 수 있었다. $1100^{\circ} \mathrm{C}(\mathrm{c})$ 에서 는 가장 두꺼운 산화층을 형성하였으며 내부에 생 성된 산화물도 가장 깊게 나타나 현저한 산화가 일 어난 것을 알 수 있다. 또한 $\mathrm{Al}_{2} \mathrm{O}_{3}$ 층을 따라 다량 의 Fe-rich 산화물도 함께 발달되어 있는 것을 관찰 하였다.

\section{4. 고 찰}

본 연구의 실험 결과에서는 $\mathrm{Fe}-22 \% \mathrm{Cr}-5.8 \% \mathrm{Al}$ 합 금의 시간 및 온도에 따른 고온 산화 결과를 제시 하였다. 또한 미세조직 관찰 및 상분석을 통해 온 도가 증가 함에 따라 산화물의 생성이 단계적으로 일어난다는 것을 밝힌 바 있다. 산기의 산화 증량 (그림 2) 값을 바탕으로 동일한 시간 조건에서 산 화 속도를 비교하고자 산화 초기 시간(30시간: 초 기 30 시간까지는 일반적인 parabolic 산화 거동을 나타냄)에 대한 산화 속도 상수 $\left(\mathrm{K}_{\mathrm{p}}\right)$ 를 측정하였다. 산화 속도 상수는 다음의 식을 통해 계산하였으며 
(a)

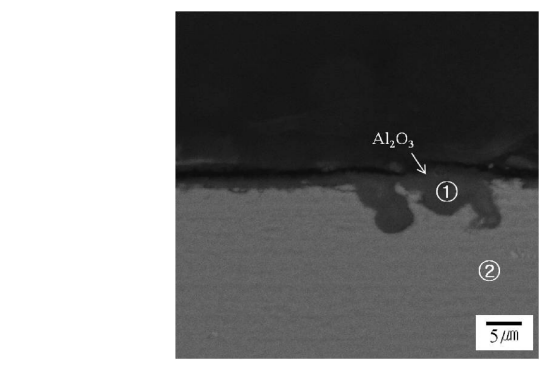

\begin{tabular}{cccccc}
\hline & $\mathrm{Fe}$ & $\mathrm{Cr}$ & $\mathrm{Al}$ & $\mathrm{O}$ & $(\mathrm{Wt} \%)$ \\
\hline (1) & 1.605 & 1.471 & 63.05 & 33.86 & 100 \\
(2) & 71.17 & 19.37 & 7.175 & 2.275 & 100 \\
\hline
\end{tabular}

(b)
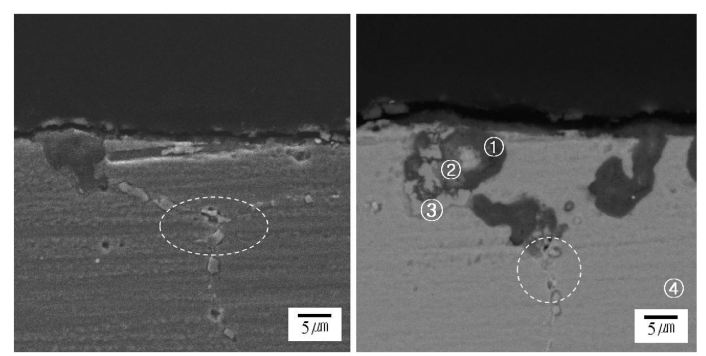

\begin{tabular}{cccccc}
\hline & $\mathrm{Fe}$ & $\mathrm{Cr}$ & $\mathrm{Al}$ & $\mathrm{O}$ & $(\mathrm{Wt} \%)$ \\
\hline (1) & 2.805 & 3.792 & 55.897 & 37.505 & 100 \\
$(2)$ & 1.106 & 27.39 & 8.187 & 63.316 & 100 \\
(3) & 40.797 & 35.02 & 6.626 & 17.55 & 100 \\
(4) & 60.819 & 19.637 & 13.107 & 6.438 & 100 \\
\hline
\end{tabular}

(c)
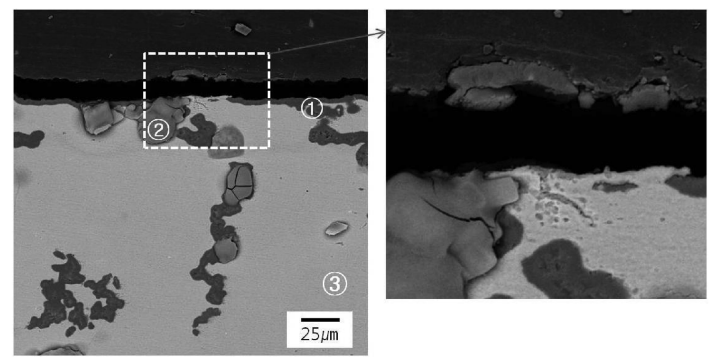

\begin{tabular}{cccccc}
\hline & $\mathrm{Fe}$ & $\mathrm{Cr}$ & $\mathrm{Al}$ & $\mathrm{O}$ & $\mathrm{Wt}(\%)$ \\
\hline (1) & 65.185 & 7.343 & 4.642 & 22.831 & 100 \\
$(2)$ & 9.237 & 2.897 & 65.789 & 22.078 & 100 \\
(3) & 71.055 & 20.996 & 6.858 & 1.092 & 100 \\
(4) & 9.237 & 2.897 & 65.789 & 22.078 & 100 \\
\hline
\end{tabular}

Fig. 6. Cross-sectional microstructure and EDS analysis result of Fe-Cr-Al alloy at (a) $900^{\circ} \mathrm{C}$, (b) $1000^{\circ} \mathrm{C}$, (c) $1100^{\circ} \mathrm{C}$.

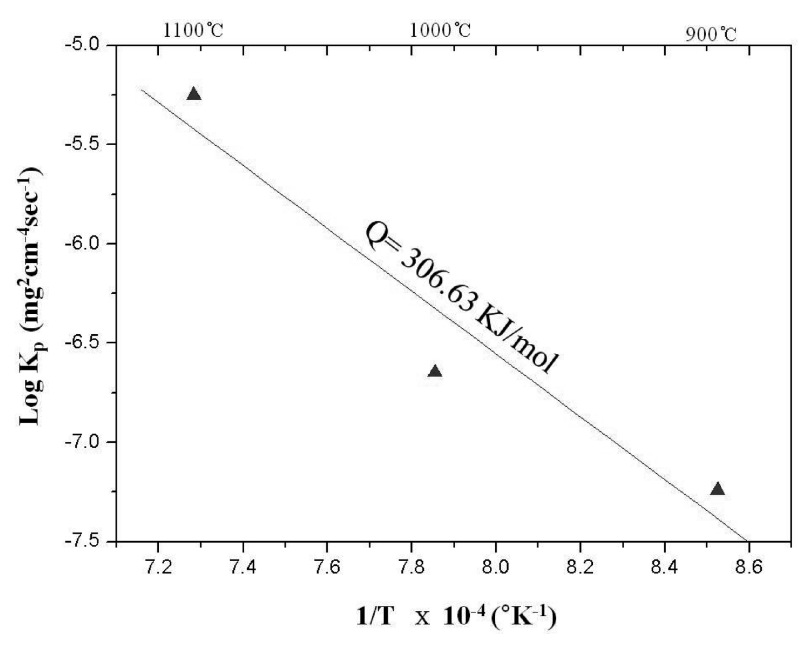

Fig. 7. Parabolic oxidation rate constant and activation energy in oxidation of $\mathrm{Fe}-\mathrm{Cr}-\mathrm{Al}$ at $900^{\circ} \mathrm{C} \sim 1100^{\circ} \mathrm{C}$.

그 결과를 그림 7에 도시하였다.

$$
\mathrm{W}^{2}=\mathrm{K}_{\mathrm{p}} \times \mathrm{t}
$$

그 결과 온도에 따라 $\mathrm{K}_{\mathrm{p}}$ 값은 직선적인 관계를 나 타냈으며, $900^{\circ} \mathrm{C}$ 에서 $1100^{\circ} \mathrm{C}$ 로 온도가 증가함에 따 라 $-7.238\left(\mathrm{mg}^{2} \mathrm{~cm}^{-4} \mathrm{sec}^{-1}\right)$ 에서 $-5.249\left(\mathrm{mg}^{2} \mathrm{~cm}^{-4} \mathrm{sec}^{-1}\right)$ 로 값이 증가하여 나타났다. 이것은 산화 속도가 온도 에 의존해 나타나는 결과로 높은 온도에서 가장 빠
른 산화가 일어남을 의미한다. 그림 7을 바탕으로 $\mathrm{Fe}-22 \% \mathrm{Cr}-5.8 \% \mathrm{Al}$ 합금에 대한 활성화 에너지 값을 $900^{\circ} \mathrm{C}$ 에서 $1100^{\circ} \mathrm{C}$ 까지 온도 구간에서 각각의 $\mathrm{K}_{\mathrm{p}}$ 값 을 온도의 역수에 관해 나타낸 그림의 기울기와 다 음의 식 (2)를 통해 계산하였다. 얻어진 값은 $306.63 \mathrm{KJ} / \mathrm{mol}$ 로 나타났다.

$$
\mathrm{K}_{\mathrm{p}}=\mathrm{K}_{0} \exp (-\mathrm{Q} / \mathrm{RT})
$$

이때 $\mathrm{K}_{0}$ : 상수, $\mathrm{R}$ : 기체상수, $\mathrm{T}$ : 절대 온도이다. Shin 등 ${ }^{19}$ 은 온도가 $1323 \mathrm{~K}$ 에서 $1473 \mathrm{~K}$ 일 때 $\mathrm{Fe}-$ $20 \% \mathrm{Cr}-5 \% \mathrm{Al}$ 의 활성화 에너지를 $282 \mathrm{KJ} / \mathrm{mol}$ 이라 발 표하였다. 이것은 $\mathrm{Al}_{2} \mathrm{O}_{3}$ 산화층을 통과하는 산소이 온의 활성화 에너지로 제시되었으며 본 연구 결과 에서도 유사한 값을 얻었다.

이상의 결과들을 요약하여 $\mathrm{Fe}-22 \% \mathrm{Cr}-5.8 \% \mathrm{Al}$ 합 금의 시간 및 온도에 따른 고온 산화 거동 모식도 를 그림 8에 나타내었다. 세 온도 모두 시간이 증 가함에 따라 산화층 성장이 일어나며 온도가 증가 함에 따라 산화물이 단계적으로 생성된다. 즉 $900^{\circ} \mathrm{C}$ 에서는 표면에 고온에서 안정한 $\mathrm{Al}_{2} \mathrm{O}_{3}$ 가 whisker형 으로 생성되었으며 일부가 내부에 산화물이 형성 되지만 비교적 안정하게 기지를 보호하는 역할을 한다. 이러한 whisker 형의 산화물과 관련하여 


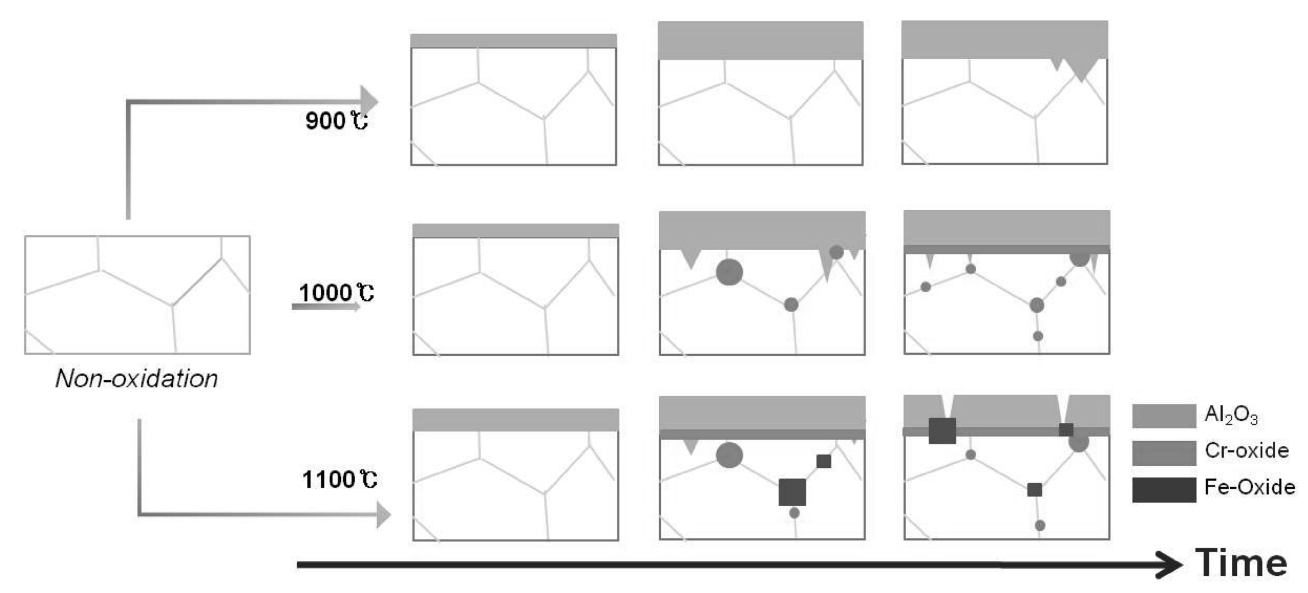

Fig. 8. Schematic illustration of temperature oxidation behaviors of Fe-22Cr-5.8Al alloy.

Borchardt 등 ${ }^{4,18)}$ 은 $\mathrm{Fe}-23 \mathrm{Cr}-5 \mathrm{Al}$ 합금에서 $\mathrm{Al}_{2} \mathrm{O}_{3}$ 산 화물의 경우 비교적 낮은 산화 온도에서 whisker형 의 산화물이 형성될 수 있으며 산화 스케일 내부의 $\mathrm{Al}$ 이 외부 확산으로 인하여 성장할 수 있다고 보고 한 바 있다. 본 연구에서도 표면 산화물 관찰 결과 (그림 3) $1000^{\circ} \mathrm{C}, 1100^{\circ} \mathrm{C}$ 에서는 whisker형의 산화물 이 발견되지 않았다. $1000^{\circ} \mathrm{C}$ 에서는 $900^{\circ} \mathrm{C}$ 에 비해 두꺼운 산화층을 형성하며 온도가 증가함에 따라 많은 $\mathrm{Al}$ 의 소진이 일어나고 $\mathrm{O}_{2}$ 의 확산이 활발해 지 게 되어 기지에 있는 $\mathrm{Cr}$ 과 결합하여 $\mathrm{Al}_{2} \mathrm{O}_{3}$ 층 아래 에 Cr-rich 산화물이 생성되어 두 가지 형태의 산화 층을 형성하게 된다. 또한 동시에 내부 결정립계에 서 $(\mathrm{Fe}, \mathrm{Cr})$-rich oxide가 생성되기 시작한다. 이와 같이 내부에 형성된 산화물은 그림 3 의 표면 산화 층 관찰에서는 나타나지 않았지만 추가적으로 weight gain의 증가(그림 2)에 기여할 것으로 사료된다. 가 장 많은 산화가 진행되어 급격한 산화 증량 기울기 를 보인 $1100^{\circ} \mathrm{C}$ 의 경우 기지 내 $\mathrm{Al}$ 의 외부 확산이 활발히 일어나 많은 양의 $\mathrm{Al}_{2} \mathrm{O}_{3}$ 를 생성시켜 두꺼운 산화층을 형성시킨다. 또한 기지 내 $\mathrm{Al}$ 의 양이 거 의 고갈되어 더 이상의 보호막 형성을 하지 못하면 $\mathrm{O}_{2}$ 의 새로운 확산 경로가 생성되어 기지 내 $\mathrm{Fe}, \mathrm{Cr}$ 의 결합이 용이해져 결정립계에 다량의 $(\mathrm{Fe}, \mathrm{Cr})-$ rich 산화물을 생성시킨다. Ishii 등 ${ }^{20)}$ 은 $\mathrm{Fe}-(20-$ $25) \% \mathrm{Cr}-5 \% \mathrm{Al}$ 합금의 고온 산화( $1423 \mathrm{~K}-1473)$ 시 $\mathrm{Fe}_{2} \mathrm{O}_{3}$ 가 $\mathrm{Al}_{2} \mathrm{O}_{3}$ 층을 파괴함으로써 산소의 새로운 확 산경로를 제공하여 breaka way에 도달한다고 보고 한 바 있다. 본 연구에서도 그림 6의 (c)에서 관찰 할 수 있듯이 금속 기지의 $\mathrm{Fe}$ 가 산화되면서 표면 에 $\mathrm{Fe}$ 계 산화물이 형성되어 breakaway가 일어나는 것을 관찰하였으며, $\mathrm{Fe}$ 계 산화물이 생성된 이후부 터 급격한 산화의 추가 진행이 일어나는 것을 확인 할 수 있었다. 즉 $\mathrm{Fe}-22 \% \mathrm{Cr}-5.8 \% \mathrm{Al}$ 합금의 산화에
서 결정립계에서 생성된 $\mathrm{Cr}$ 이나 $\mathrm{Fe}$ 계 산화물들은 보호성 역할을 하는 $\mathrm{Al}_{2} \mathrm{O}_{3}$ 산화층에 균열을 일으켜 외부로 성장하게 되어 내산화성을 저하시키는 요인 으로 작용하는 것으로 판단된다.

\section{5. 결 론}

본 연구에서는 $\mathrm{Fe}-22 \% \mathrm{Cr}-5.8 \% \mathrm{Al}$ 합금의 시간 및 온도에 따른 고온산화 거동을 조사하여 미세조직 및 산화 생성상과 관련해 고온 산화 미세 기구에 대해 규명하였으며 다음과 같은 결론을 도출해 낼 수 있었다.

(1) $\mathrm{Fe}-22 \% \mathrm{Cr}-5.8 \% \mathrm{Al}$ 합금의 세 가지 온도 조건 의 고온 산화 실험 결과 시간의 증가에 따라 온도 별로 산화 증량 거동이 각각 다르게 나타났다. $900^{\circ} \mathrm{C}$ 에 비해 $1100^{\circ} \mathrm{C}$ 에서 현저히 높은 산화 증량 값을 나타나면서 가장 많은 양의 산화가 진행되었다. 본 합금의 고온 산화에 대한 활성화 에너지는 306.63 $\mathrm{KJ} / \mathrm{mol}$ 로 얻어졌다.

(2) 고온 산화 온도에 따라 산화물의 성장의 차이 로 인해 표면 산화물의 형상이 다르게 나타났으며 $900^{\circ} \mathrm{C}$ 에서 Whisker 형태의 산화물이 형성되었고 많 은 양의 산화가 진행된 $1100^{\circ} \mathrm{C}$ 에서는 산화층이 cluster를 이루며 거대한 산화층이 형성되었다.

(3) 세 가지 온도에서 시간에 따른 고온 산화 시 생성되는 산화물은 $900^{\circ} \mathrm{C} 1000^{\circ} \mathrm{C}$ 에서 $\mathrm{Al}_{2} \mathrm{O}_{3}, \mathrm{Cr}-$ rich 산화물이 생성되었으며 $1100^{\circ} \mathrm{C}$ 에서는 $\mathrm{FeCr}_{2} \mathrm{O}_{4}$, $\mathrm{Fe}_{3} \mathrm{O}_{4}$ 가 추가적으로 생성되었다. 각각의 생성된 산 화물은 $900^{\circ} \mathrm{C}$ 에서 $1100^{\circ} \mathrm{C}$ 로 온도가 증가함에 따라 활발한 확산으로 $\mathrm{Al}$ 이 더 이상 보호막 형성을 하 지 못하고 새로운 산화물이 형성되는 것으로 사료 되며 높은 온도에서 추가 산화물이 더 빠른 시간에 형성되었다. 
(4) $\mathrm{Fe}-22 \% \mathrm{Cr}-5.8 \% \mathrm{Al}$ 합금은 산화 초기(30시간) 이내에 $\mathrm{Al}_{2} \mathrm{O}_{3}$ 생성을 일으켜 $\mathrm{Al}_{2} \mathrm{O}_{3}$ 성장에 따라 산 화가 진행된다. 그 이후 $\mathrm{Al}$ 이 거의 소진되면 내부 결정립계 및 내부에 새로운 산화층이 형성되며 직 선적인 질량 변화가 나타난다. 이후 시간이 지남에 따라 결정립계에서 생성된 $\mathrm{Cr}$ 이나 $\mathrm{Fe}$ 계 산화물들 이 이전 산화층에 균열을 일으켜 급격한 산화를 가 져오는 것으로 나타났다.

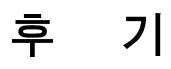

본 연구는 지식경제부의 “소재원천기술개발사업” 의 지원으로 수행되었으며 이에 감사 드립니다.

\section{참고문헌}

1. J. G. Smeggil, A. W. Funkenbusch, N. S. Bornstein, Metall. Trans., 17 (1986) 923.

2. J. L. Smialek, Metall. Trans., 9A (1979) 309.

3. P. A. Mari, J. M Chaiz, J. P. larin, Oxidation of Metal, 17 (1982) 315.

4. J. Jedlinski, G. Borchardt, Oxidation of Metals 36 (1991) 317.

5. M. H. Lagrange, A. M. Huntz, J. Y. Laval, Ann. Chim. Fr, 12 (1987) 9.

6. I. M. Wolff, L. E. Iorio et al., Mater. Sci. Eng.,
A241 (1998) 264.

7. Z. L. Zhang, D. Y. Li, X. Q. Dong, Acta Metall. Sin., 20 (2007) 87.

8. S. E. Sadique, A. H. Mollah, M. M. Ali et al., J. Corros. Sci. Eng., 1 (2000) 18.

9. Y. Niu, S. Wang, F. Gao et al., Corros. Sci., 50 (2008) 345.

10. R. Cueff, H. Buscail, E. Caudron et al., Corros. Sci., 45 (2003) 1815.

11. D. P. Whittle, J. Stringer, Phil. Trans. R. Soc. Lond, A295 (1980) 309.

12. F. Clemendot, J. M. Gras, J. C. van Duysen, J. de Physique IV, 3 (1993) 291.

13. S. C. Choi, S. Park et al., Kor. J. Met. Mater, 35(1) (1997) 136.

14. K. S. Lee, H. Y. Ra, J. Met. Mater., 34(1) (1996) 936.

15. S. Hiroshi, K. Masski, Y. Keiichi, Kawasaki Steel Technical Report No., 31 (1994).

16. B. G. Moon, S. C. Kang, G. M. Kim, J. Corros Sci. Soc. of Korea, 25(2) (1996) 149.

17. Z. L. Zhang, X. J. Ahang, T. J. Pan et al., Gangtie Yanjiu, 35(3) (2007) 38.

18. W. J. Quadakkers, J. Jedlinski, G. Borchardt et al., Appl Surf. Sci., 47 (1991) 261.

19. Y. C. Shin, K. S. Lee, W. W. Park, Kor. J. Met. Mater., 34(7) (1996) 936.

20. K. Ishii, T. Kawasaki, J. Jpn. Inst. Met., 56 (1992) 854. 